Research Report

\title{
Encouraging Parents to Participate in "KESGILUT" (Dental and Oral Health) Program Using “AWAS” (Aku Wedi Anakku Gigis) Educational Book
}

\author{
Nadya Adina Zuhdi, Karina Awanis Adla, Gita Alethea Kristi Maharani, Zalfa Karimah, Theresa Dian \\ Krissanti, Yuliana Merlindika Sembadani, Innocencio Kresna, Almira Rachmawati, Andi Adani Nurrezeki, \\ Callista Gladys Fionna, Zhafira Putri Syahdryani and R Darmawan Setijanto \\ Departement Dental Public Health, \\ Faculty of Dental Medicine, Universitas Airlangga \\ Surabaya - Indonesia
}

\begin{abstract}
Background: A preliminary epidemiological study of three kindergartens in Embong Kaliasin Village under Ketabang Public Health Center, Surabaya coverage revealed that $63 \%$ of the kindergarteners have dental caries. The study also found that only $8 \%$ of them received dental treatment. The remaining $92 \%$ of kindergarteners never had dental treatment because uncovered health insurance, unavailability of parents during working days and hours, mother's education level, mother's medical history, paternal support in dental and oral health care. Promotive, preventive, and referral efforts can be achieved by empowering health cadres. The empowerment program addressed maternal reluctance in participating "KESGILUT" program by providing the "AWAS" educational book. Purpose: We expect that the program could increase mothers' knowledge levels on dental and oral health as well as encourage them to participate in child dental and oral health care. Methods: The health education method was parental mentoring with a group approach. The parents of Manguni kindergarteners receiving the "AWAS" educational book as a group. The media of the program was the "AWAS" educational book. It covered information about dental and oral health, including primary and secondary dentition, stages of dental caries, correct tooth brushing, nutritious food for teeth, and preventing dental caries. The evaluation method of this program is using pre-post test analysis. Results: There is an increasement in post test score (68\%) to post-test score (83\%). Conclusion: This program is effective to increase mother's knowledge about dental and oral health.
\end{abstract}

Keywords: dental caries; parents; oral health

Correspondence: R Darmawan Setijanto, Department of Dental Public Health, Faculty of Dental Medicine, Universitas Airlangga, Jl. Prof. Dr. Moestopo 47 Surabaya 60132 - Indonesia. Email: r-darmawan-s@fkg.unair.ac.id

\section{INTRODUCTION}

Ketabang Public Health Center provides inpatient and outpatient care, it is located in Genteng District and it covers Ketabang Village and Embong Kaliasin Village, Surabaya. The Ketabang Public Health Center has one supporting branch (Puskesmas Pembantu) and two village health posts (Pos Kesehatan Kelurahan).

The secondary data of child admission in the poly dental unit of Ketabang Public Health Center showed that pulpitis was the most common oral health problem. It ranked sixth out of a total of fifteen most common diseases in the Ketabang Public Health Center. Pulpitis was the most diagnosed child disease in the Ketabang Public Health Center. 125 children were suffering from pulpitis from May to July 2018.
There are three main components of child dental care. The components form a triangle, and it is known as Pediatric Dentistry Treatment Triangle. Each corner represents one component (dentist, family, especially mother, or children), and children is located at the upper corner. These components are dynamically interconnected.

Family, especially mothers, has a critical role in pediatric dental health care as children are still dependent on their parents. Maternal attitude and behavior significantly affect children in maintaining dental and oral health. Mothers are the motivator, educator, and facilitator to their children. ${ }^{2}$

The American Academy of Pediatric Dentistry (AAPD) and the American Dental Association (ADA) recommend a dental visit six months after the first primary teeth erupt or equal to one year. During the visit, the dentist can detect early signs of carious lesions, assess caries risk, evaluate 
tooth development, provide dietary guidance and counseling and motivate parents to adopt oral disease prevention behaviors. $^{3}$

In Indonesia, many parents did not aware of the importance of dental care, primarily pediatric dental care. Parents will have pediatric dental treatment only if their children have dental problems. Parents, especially mothers, should be aware of the importance of pediatric dental care because deciduous teeth will significantly affect permanent teeth. However, many parents downplay the dental health problems of deciduous teeth as they will be replaced with permanent teeth.

There were only 385 admissions out of 1,587 0-6-yearold children to the pediatric dental care unit of Ketabang Public Health Center from May to July 2018. This indicated a low dental visitation in the pediatric dental treatment unit of Ketabang Public Health Center, amounting $8 \%$ of the total population.

An interview with a medical officer of the Ketabang Public Health Center revealed that there have been regular dental check-up efforts in a partnered kindergarten. Kindergarteners with dental health problems were then referred for dental treatment. However, the effort was unsuccessful because the parents of the kindergarteners did not attend the follow-up pediatric dental treatment.

\section{MATERIALS AND METHODS}

This program aims to Encouraging parents to participate in the KESGILUT program using "AWAS” (Aku Wedi Anakku Gigis) educational book so that they become aware of the importance of dental health and will be willing to admit their children for pediatric dental treatment. The health education method was parental mentoring with a group approach. The parents of Manguni kindergarteners receiving the "AWAS" educational book as a group. The media of the program was the "AWAS" educational book. It covered information about dental and oral health, including primary and secondary dentition, stages of dental caries, correct tooth brushing,

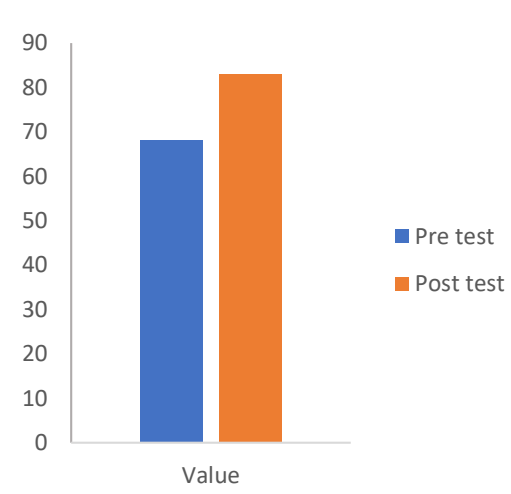

Figure 1. The mean of the pre-test and post-test results empowerment program for parents to increase their knowledge levels about child dental and oral health using the "AWAS" educational book. nutritious food for teeth, and preventing dental caries. They were given pre-test before receiving counseling about "AWAS" book. They were also doing post-test afterwards. The evaluation method of this program is using pre-post test analysis.

\section{RESULTS}

The empowerment program was conducted at Manguni Kindergarten on 30 August 2018. The program involved 10 mothers of the kindergarteners. An evaluation was carried out upon program completion (Figure 1 and Table 1).

\section{DISCUSSION}

The preliminary research result showed that lower knowledge levels and reluctance were the risk factors of child dental health problems, including reluctance to admit their children for a dental check-up. According to Wening 2020 , one of the efforts to convey health information is through counseling. Verbal counseling methods are effective for increasing the knowledge possessed by the audience or participants of the counseling. ${ }^{4,5}$ However, children who are growing up, can not absorb information about health to the fullest. Material about health and healthy life behavior is considered heavy enough to be accepted by children. ${ }^{6}$ Therefore, the role of parents in delivering health messages is very important, given that parents have a high intensity of interaction with children. ${ }^{7}$

Forms of counseling with verbal techniques and using PowerPoint presentations are effective, but they are no longer new to the audience. This causes boredom and boredom when listening to the material provided. The use of multimedia in counseling is a breakthrough for innovative counseling methods. Various media (other than presentations) can stimulate the senses and increase

Table 1. Pre and post test quetionnaire results

\begin{tabular}{|c|c|c|}
\hline Question & $\begin{array}{r}\text { Pre- } \\
\text { test }\end{array}$ & $\begin{array}{c}\text { Post- } \\
\text { test }\end{array}$ \\
\hline Enamel is the outer part of a tooth. & $30 \%$ & $70 \%$ \\
\hline There is a total of 20 deciduous teeth. & $100 \%$ & $100 \%$ \\
\hline Incisors are the first teeth to erupt. & $100 \%$ & $100 \%$ \\
\hline $\begin{array}{l}\text { The permanent tooth first erupts at age } 6-7 \\
\text { years old. }\end{array}$ & $50 \%$ & $70 \%$ \\
\hline $\begin{array}{l}\text { A fissure sealant is a thin material that at } \\
\text { coats the surface of chewing molars and } \\
\text { not reachable by a toothbrush. }\end{array}$ & $10 \%$ & $70 \%$ \\
\hline Ideal 6-month dental visit. & $90 \%$ & $90 \%$ \\
\hline $\begin{array}{l}\text { Introduce children to dentist begins when a } \\
\text { deciduous tooth begins to erupt } \\
\text { The right time for tooth brushing is }\end{array}$ & $60 \%$ & $80 \%$ \\
\hline $\begin{array}{l}\text { morning day after breakfast and evening } \\
\text { before sleeping }\end{array}$ & $100 \%$ & $100 \%$ \\
\hline $\begin{array}{l}\text { Plaque is a natural layer that sticks to teeth } \\
\text { and can cause tooth decay }\end{array}$ & $60 \%$ & $60 \%$ \\
\hline $\begin{array}{l}\text { The pea-size toothpaste amount for chil- } \\
\text { dren is correct. }\end{array}$ & $30 \%$ & $100 \%$ \\
\hline
\end{tabular}


the ability to absorb information..$^{89}$ Departing from this theory, the Illustration Book is used in everyday language as a medium for oral health counseling for mothers and parents.

The book was bilingual — Indonesian and Javanese - to accommodate the program participants. The SWOT analysis: (1) Strength: The book contains interesting illustrations for children, and the information was delivered in Indonesian and Javanese with the Surabaya dialect. (2) Weakness: Some program participants found that the material was difficult to understand because it was new to them. Parental assistance was also inefficient due to time constraints. (3) Opportunity: The program addressed the issue that parents of the kindergarteners were not aware of the importance of dental health in children. (4) Threat: The parents might still believe that dental care in children is not essential, and since the program took place on weekdays, not all parents attended the program.

The program was motivated by the high prevalence ratio and parental reluctance to admit their children for dental care. The program was expected to address the risk factors and encourage parents to admit their children to pediatric dental care.

The program implemented a two-way communication strategy for better engagement with the participants. The result shows that there was a $25 \%$ increase in knowledge levels about pediatric dental and oral health care. The program outcome was not $100 \%$. This indicates that the program was inefficient. Time constraints and limited facilities were believed to cause inefficiency.

With an increase in maternal knowledge about oral health, it is expected to have an impact on improving children's dental health. This is supported by the results of the 2016 Haque study which states that increasing health knowledge is directly proportional to improving health quality. ${ }^{10}$

\section{CONCLUSION}

“AWAS" (Aku Wedi Anakku Gigis) educational book helped the parents learn about the importance of dental and oral health in children. We expect that the "AWAS" educational book can be used for learning activities in
Manguni Kindergarten. It is also important to update and add more information to the educational book. Furthermore, a more thorough and engaging program is needed in promoting dental health care in children.

\section{REFERENCES}

1. Gharlipour Z, Hazavehei SMM, Moeini B, Nazari M, Beigi AM, Tavassoli E, et al. The effect of preventive educational program in cigarette smoking: Extended Parallel Process Model. J Educ Health Promot. 2015;4:4.

2. E. B, A. H, T. MM. Oral health behavior of parents as a predictor of oral health status of their children. ISRN Dent. 2013;2013:1-6.

3. America's DP. Guideline on caries-risk assessment and management for infants, children, and adolescents. Vol. 38, Pediatric Dentistry. American Academy of Pediatric Dentistry; 2016. p. 142-9.

4. Palupi R, Berniyanti T, Bramantoro T, Wening GS, Kusumo A, Zamzam A. Local myth and facts approach for maximizing oral health promotion training among the school teachers and parents in urban village. J Int Oral Heal. 2019 Jan 1;11(7):34.

5. John K. Health Promotion. London: Oxford University Press; 2014. $31 \mathrm{p}$.

6. Manohar B, Surendra Reddy N, Vyshnavi P, Sravya Sruthi P. Assessment of knowledge, attitude and practice of mothers with severe acute malnutrition children regarding child feeding. Int J Pharm Clin Res. 2015;10(5):150-4.

7. Fadare O, Amare M, Mavrotas G, Akerele D, Ogunniyi A. Mother's nutrition-related knowledge and child nutrition outcomes: Empirical evidence from Nigeria. Vellakkal S, editor. PLoS One. 2019 Feb 28;14(2):e0212775.

8. Stein C, Santos NML, Hilgert JB, Hugo FN. Effectiveness of oral health education on oral hygiene and dental caries in schoolchildren: Systematic review and meta-analysis. Community Dent Oral Epidemiol. 2018 Feb 1;46(1):30-7.

9. Alhayek AA, Alsulaiman M, Almuhanna H, Alsalem M, Althaqib M, Alyousef A, et al. The effect of conventional oral health education versus animation on the perception of Saudi males in primary school children. J Int Oral Heal. 2018 May $1 ; 10(3): 121$.

10. Haque SE, Rahman M, Itsuko K, Mutahara M, Kayako $\mathrm{S}$, Tsutsumi A, et al. Effect of a school-based oral health education in preventing untreated dental caries and increasing knowledge, attitude, and practices among adolescents in Bangladesh. BMC Oral Health. 2016 Mar 25;16(1). 